University of Rhode Island

DigitalCommons@URI

Civil \& Environmental Engineering Faculty

Publications

Civil \& Environmental Engineering

9-8-2015

\title{
Effects of Dysprosium Oxide Nanoparticles on Escherichia coli
}

\author{
N. M. Anaya \\ University of Rhode Island \\ F. Soloman \\ University of Rhode Island \\ Vinka Oyanedel-Craver \\ University of Rhode Island, craver@uri.edu
}

Follow this and additional works at: https://digitalcommons.uri.edu/cve_facpubs

Terms of Use

All rights reserved under copyright.

\section{Citation/Publisher Attribution}

Anaya, N. M., Solomon, F., \& Oyanedel-Craver, V. (2015). Effects of Dysprosium Oxide Nanoparticles on Escherichia coli. Envrio. Sci.: Nano., 3, 67-73. doi: 10.1039/C5EN00074B

Available at: http://dx.doi.org/10.1039/C5EN00074B

This Article is brought to you for free and open access by the Civil \& Environmental Engineering at DigitalCommons@URI. It has been accepted for inclusion in Civil \& Environmental Engineering Faculty Publications by an authorized administrator of DigitalCommons@URI. For more information, please contact digitalcommonsgroup@uri.edu. 


\section{Environmental Science \\ Nano}

\section{Accepted Manuscript}

This article can be cited before page numbers have been issued, to do this please use: N. M. Anaya, V.

Oyanedel-Craver and F. Solomon, Environ. Sci.: Nano, 2015, DOI: 10.1039/C5EN00074B.

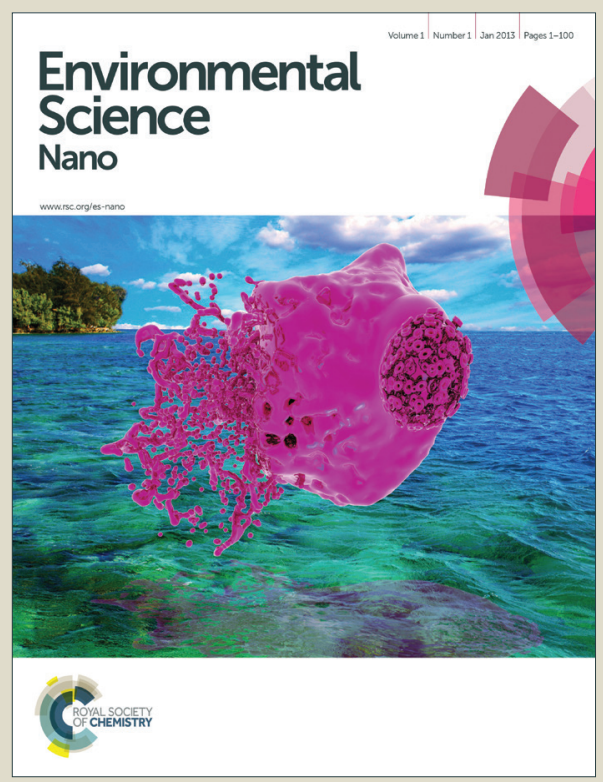

This is an Accepted Manuscript, which has been through the Royal Society of Chemistry peer review process and has been accepted for publication.

Accepted Manuscripts are published online shortly after acceptance, before technical editing, formatting and proof reading. Using this free service, authors can make their results available to the community, in citable form, before we publish the edited article. We will replace this Accepted Manuscript with the edited and formatted Advance Article as soon as it is available.

You can find more information about Accepted Manuscripts in the Information for Authors.

Please note that technical editing may introduce minor changes to the text and/or graphics, which may alter content. The journal's standard Terms \& Conditions and the Ethical guidelines still apply. In no event shall the Royal Society of Chemistry be held responsible for any errors or omissions in this Accepted Manuscript or any consequences arising from the use of any information it contains. 


\section{Nano Impact Statement}

This study offers new insights into dysprosium oxide nanoparticles $\left(\mathrm{nDy}_{2} \mathrm{O}_{3}\right)$ exposure on E. coli with respect to its metabolic activity and structural integrity. The toxicity of $\mathrm{nDy}_{2} \mathrm{O}_{3}$ was evaluated for two array-based techniques, Live/Dead and respirometric assays. Our work is novel since new $\mathrm{nDy}_{2} \mathrm{O}_{3}$ toxicity data was produced covering manufacturer recommendations for toxicity assessments, environmental and industrial $\mathrm{nDy}_{2} \mathrm{O}_{3}$ effluent concentrations and metabolic activity. This is highly relevant to the evaluation of the toxic effect of nanoparticles since the physicochemical properties of the nanoparticles can differ greatly depending of the physicochemical characteristics of the aqueous solution. With an understanding of the nanoparticles fate in aqueous media, a careful selection of appropriate toxicological methodologies can be made to improve the accuracy of future nanotoxicological studies. 


\section{Journal Name}

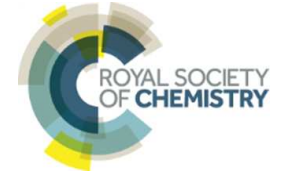

\section{ARTICLE}

\section{Effects of Dysprosium Oxide Nanoparticles on Escherichia coli}

Received 00th January 20xx, Accepted 00th January 20xx

DOI: $10.1039 / x 0 x \times 00000 x$

www.rsc.org/

\section{N. M. Anaya ${ }^{a}$, F. Solomon ${ }^{a}$ and V. Oyanedel-Craver ${ }^{a}$}

There is increasing interest in the study of dysprosium oxide nanoparticles $\left(\mathrm{nDy}_{2} \mathrm{O}_{3}\right)$ for biomedical applications due to their fluorescent and paramagnetic properties. However, the fate of $n D y_{2} \mathrm{O}_{3}$, and their effects on natural biological systems, are a growing concern.

\begin{abstract}
This study assessed the toxicity of $\mathrm{nDy}_{2} \mathrm{O}_{3}$ on Escherichia coli for concentrations between 0.02 and $2 \mathrm{mg} / \mathrm{L}$, exposed to three concentrations of $\mathrm{NaCl}(8,500 ; 850$ and $85 \mathrm{mg} / \mathrm{L})$ and three glucose concentrations $(35,70,140 \mathrm{mg} / \mathrm{L})$. The ranges of these variables were selected to cover manufacturer recommendations of analytical methodologies for toxicity assessment, environmental and industrial $\mathrm{nDy}_{2} \mathrm{O}_{3}$ effluent concentrations, and metabolic activity. Two array-based toxicity techniques were used to evaluate the 27 combinations of conditions. Fluorescent dyes (Live/Dead) and respirometric assays were used to measure the undisturbed cell membrane (UCM) and remaining respiration percentage (RRP), respectively.
\end{abstract}

\begin{abstract}
Respirometric tests showed a higher toxic effect than Live/Dead test assays, indicating that metabolic processes are more affected than the physical structure of the cell by exposure to $\mathrm{nDy}_{2} \mathrm{O}_{3}$. After exposing the bacteria to concentrations of 2.0 $\mathrm{mg} / \mathrm{L}$ uncoated $\mathrm{nDy}_{2} \mathrm{O}_{3}$ for $2 \mathrm{hrs}$ at $85 \mathrm{mg} / \mathrm{L}$ of $\mathrm{NaCl}$ and $140 \mathrm{mg} / \mathrm{L}$ of glucose, the RRP and UCM decreased to $43 \%$ and $88 \%$, respectively. Dysprosium ions $\left(\mathrm{Dy}^{+3}\right)$ toxicity measurement suggested that $\mathrm{Dy}^{+3}$ was the main contributor to the overall toxicity.
\end{abstract}

\section{Introduction}

Gadolinium, holmium and dysprosium belong to the lanthanide oxide-based nanoparticles (LnONps), which have acquired more relevance in recent years in regard to the locating, diagnosing and treating of diseases ${ }^{1-3}$. LnONps have unique paramagnetic properties that allow greater spatial and temporal resolution through a higher signal-to-noise ratio. These properties play a fundamental role in acquiring and enhancing the contrast in $T_{1}$ or $T_{2}$ magnetic resonance images (MRI) ${ }^{4,5}$. Due to the higher sensitivity provided by the LnONps, the MRI contrast is improved and the $T_{1}$ or $T_{2}$ relaxation times are discriminatorily shortened in the region of interest ${ }^{6}$.

Dysprosium oxide nanoparticles $\left(\mathrm{nDy}_{2} \mathrm{O}_{3}\right)$ have recently received increasing attention due to their potential applications in the biomedical field ${ }^{4,5}$ including cancer research, new drug screening, and the delivery of drug applications ${ }^{2,7,8}$. However, the fate of $\mathrm{nDy}_{2} \mathrm{O}_{3}$ and their effects

\footnotetext{
${ }^{a}$ Department of Civil and Environmental Engineering, Bliss hall 203, University of Rhode Island, Kingston, RI, 02881, USA. E-mail: nelson_anaya@my.uri.edu; fsolomon@my.uri.edu; craver@uri.edu.Phone: (401)-874-2784. Fax: (401)-8742786

Electronic Supplementary Information (ESI) available: [details of any supplementary information available should be included here]. See DOI: $10.1039 / x 0 \times x 00000 x$
}

on natural biological systems are growing concerns ${ }^{9} \cdot \mathrm{nDy}_{2} \mathrm{O}_{3}$ will enter into aquatic and land environments through wastewater treatment facility effluent and wastewater sludge due to an inability to retain and or remove these nanoparticles completely ${ }^{10}$. Moreover, the release of $\mathrm{nDy}_{2} \mathrm{O}_{3}$ into land environments from agricultural applications could transport nanoparticles to surface waters via stormwater runoff and to groundwater via infiltration through the soil ${ }^{10,11}$.

Previous studies have provided limited insight into the toxic effects of $\mathrm{nDy}_{2} \mathrm{O}_{3}$ and $\mathrm{Dy}$ ions on natural systems. Kattel et al. ${ }^{12}$ investigated the in vitro toxicity effect of ultra-small spherical dysprosium oxide and dysprosium hydroxide nanorods ${ }^{5}$. Both nanoparticles were coated with D-glucuronic acid and exposed to DU 145 and NTC 1469 cell lines. These studies showed that the nanoparticles were not toxic to the human cells for concentration values ranging from 0 to 37.3 $\mathrm{mg} / \mathrm{L}$.

Harper et al. ${ }^{13}$ tested 11 types of metal oxide nanoparticles, including $\mathrm{nDy}_{2} \mathrm{O}_{3}$, and found that high mortality of embryonic zebrafish was observed when they were exposed to $250 \mathrm{mg} / \mathrm{L}$ of $\mathrm{nDy}_{2} \mathrm{O}_{3}$ for 5 days of continuous waterborne conditions. In addition, concentrations of $250 \mathrm{mg} / \mathrm{L}$ for $\mathrm{nDy}_{2} \mathrm{O}_{3}$ produced morphological malformations of the zebrafish's jaw and eyes. Toxicological assessment of nanoparticles can be studied in terms of their impact on metabolic functions and cell structure such as cell viability, membrane permeation, growth and respiration. Live/Dead assay (BacLight viability kit) is a 
commonly-used method to measure cell viability ${ }^{14}$ and membrane permeation on bacteria through the integrity of cell membranes. The manufacturer of the reagents used for the Live/Dead test recommends that experiments and samples have to be prepared in specific water chemistry conditions $(8,500 \mathrm{mg} / \mathrm{L}$ of $\mathrm{NaCl})$ to avoid a decrease in staining efficiency ${ }^{14}$. Previously, the metabolic activity of bacteria has been measured using a traditional respirometric bottle test (RT). Water chemistry conditions with monovalent and divalent cations have been successfully used in the range of 10 to 1,000 $\mathrm{mg} / \mathrm{L}$; however, high concentrations of glucose (in the order of $300 \mathrm{mg} / \mathrm{L}$ ) and bacteria (in the order of $10^{9} \mathrm{CFU} / \mathrm{mL}$ ) were required to quantify a toxic response ${ }^{15}$. This type of test can be used to measure the interaction and effect of nanoparticles on microorganisms. Nevertheless, each methodology required its own range of optimal conditions, which makes it a complex process to assess toxic effects when identical water chemistry conditions are used. This is highly relevant to the evaluation of the toxic effect of nanoparticles, since the physicochemical properties of the nanoparticles (e.g., charge, aggregation, cellnanoparticle ratio and dissolution) can differ among each other and also their properties are influenced by the physicochemical characteristics of the aqueous solution.

In this study, we propose to evaluate the use of array-based dyes methods in identical water chemistry conditions and observe the effect of $\mathrm{nDy}_{2} \mathrm{O}_{3}$ and exposure on $E$. coli metabolic activity and structural integrity of $E$. coli under variable water chemistry conditions.

\section{Materials and Methods}

\subsection{Materials}

A non-pathogenic wild strain of E. coli (IDEXX laboratory) was selected for this study. $E$. coli is a gram-negative bacterium that has been found to be metabolically active in saline solution without growth ${ }^{16}$ and has been extensively studied in nanotoxicological research ${ }^{15,17,18}$. Reagents used to prepare the growth media for the bacteria - sodium chloride $(\mathrm{NaCl})$, yeast extract, and tryptone - were purchased from Sigma Aldrich. Glucose was purchased from Sigma Aldrich and used as received. Tetrazolium dye (Redox Dye Mix A) was purchased from Biolog and used to measure the respiratory responses of E. coli. Cell membrane permeation was measured using SYTO 9 and propidium iodide; both reagents were purchased from Invitrogen.

\subsection{Methods}

Hydrodynamic diameter and zeta potential were measured by Malvern Zetasizer Nano ZS, ZEN 3600, dynamic light scattering (DLS). Data was collected at $0.25 \mathrm{hrs}$ and at $2 \mathrm{hrs}$ after nanoparticles exposure to bacteria to differentiate the effect of aggregation of nanoparticles. Shape characterization of the nanoparticle was obtained by using JEOL JEM-2100 LaB6 transmission electron microscope (TEM) imaging. Ionic release from $\mathrm{nDy}_{2} \mathrm{O}_{3}$ for each condition was quantified as per Liu and Hurt $^{19}$ using centrifugal ultrafilter devices (ultra-4,3K) purchased from Amicon. Inductively-coupled plasma spectroscopy (ICP-OES optima 3100, Perkin Elmer) was used to measure the concentration of $\mathrm{nDy}_{2} \mathrm{O}_{3}$ and $\mathrm{Dy}$ ions before and after the contact times established for each of the water chemistry conditions tested. Samples were digested in nitric acid $\left(2 \% \mathrm{v} / \mathrm{v}, \mathrm{HNO}_{3}\right)$ before analysis.

Growth media consisted of $10 \mathrm{~g} / \mathrm{L} \mathrm{NaCl}, 5 \mathrm{~g} / \mathrm{L}$ yeast extract, and $10 \mathrm{~g} / \mathrm{L}$ tryptone. After the solution was prepared, it was autoclaved and then E. coli seed was added. E. coli was grown for $12 \mathrm{hrs}$ in a culture media at $37^{\circ} \mathrm{C}$. Bacteria were harvested during the logarithmic growth phase and centrifuged at 2000 rpm for $0.25 \mathrm{hrs}$. The supernatant was discarded and the pellet re-suspended in the respective $\mathrm{NaCl}$ solution ${ }^{15}$. E. coli concentration was fixed to OD670 (optical density at a wavelength of $670 \mathrm{~nm}$ ) of 2.68 using the respective $\mathrm{NaCl}$ solution. E. coli solutions were refrigerated at least $30 \mathrm{~min}$ prior to inoculation into the microplate in order to decrease the metabolism of the bacteria. This allowed for a homogenous metabolic reaction to the glucose.

Three $\mathrm{NaCl}$ concentrations were selected: $85 \mathrm{mg} / \mathrm{L}, 850 \mathrm{mg} / \mathrm{L}$ and $8500 \mathrm{mg} / \mathrm{L}$ (ionic strength $1.45 \mathrm{mM}, 14.5 \mathrm{mM}$ and 145 $\mathrm{mM}$, respectively). The lowest concentration represents the ionic strength commonly found in surface waters, ${ }^{20}$ while the highest $\mathrm{NaCl}$ concentration was selected based on the manufacturer's recommendations of the Live/Dead test ${ }^{14}$. The middle value was chosen for a three-tier comparison. Glucose concentrations in the range of $35 \mathrm{mg} / \mathrm{L}$ to $140 \mathrm{mg} / \mathrm{L}$ were used as a carbon source to evaluate $\mathrm{nDy}_{2} \mathrm{O}_{3}$ toxicity under different aerobic metabolic levels. Preliminary experiments were carried out to determine the glucose concentrations that inhibit the $E$. coli metabolic functions. The glucose concentration of $35 \mathrm{mg} / \mathrm{L}$ was the lowest limit of respiratory detection, and $140 \mathrm{mg} / \mathrm{L}$ was below the concentration $(210 \mathrm{mg} / \mathrm{L})$ that produces an inhibitory effect on E. coli.

Three concentrations of non-coated $\mathrm{Dy}_{2} \mathrm{O}_{3}$ nanoparticles $0.02 \mathrm{mg} / \mathrm{L}, 0.2 \mathrm{mg} / \mathrm{L}$ and $2.0 \mathrm{mg} / \mathrm{L}$ - were used to simulate not only environmental concentrations $(0.02 \mathrm{mg} / \mathrm{L})$, but also accidental spill scenarios $(2.0 \mathrm{mg} / \mathrm{L})$. Non-coated $\mathrm{Dy}_{2} \mathrm{O}_{3}$ nanoparticles were prepared based on the method used by Kattel et al. ${ }^{12}$

Table 1 shows the 27 conditions and the blanks tested in this study for the respirometric and Live/Dead tests using the synergy TM MX microplate reader. Blanks without $\mathrm{nDy}_{2} \mathrm{O}_{3}$, glucose and $\mathrm{NaCl}$ were analyzed for each scenario.

Table 1 Condition Matrix tested using respirometric and live/dead tests. Samples in quadruplicate were run. Glucose, $\mathrm{nDy}_{2} \mathrm{O}_{3}$ and bacteria were prepared at the same $\mathrm{NaCl}$ concentration. * represents blanks for each condition.

\begin{tabular}{|c|c|c|}
\hline $\begin{array}{c}\mathrm{NaCl} \\
{[\mathrm{mg} / \mathrm{L}]}\end{array}$ & $\begin{array}{c}\text { Glucose } \\
{[\mathrm{mg} / \mathrm{L}]}\end{array}$ & $\begin{array}{c}\mathrm{nDy} \mathbf{O}_{3} \\
{[\mathrm{mg} / \mathrm{L}]}\end{array}$ \\
\hline \multirow{2}{*}{$0^{*}$} & $0^{*}$ & $0.02,0.2,2$ \\
\cline { 2 - 3 } & 35 & $0^{*}, 0.02,0.2,2$ \\
\cline { 2 - 3 } & 70 & $0^{*}, 0.02,0.2,2$ \\
\cline { 2 - 3 } & 140 & $0^{*}, 0.02,0.2,2$ \\
\hline \multirow{2}{*}{85} & $0^{*}$ & $0.02,0.2,2$ \\
\cline { 2 - 3 } & 35 & $0^{*}, 0.02,0.2,2$ \\
\hline
\end{tabular}




\begin{tabular}{|c|c|c|}
\hline $\begin{array}{c}\mathrm{NaCl} \\
{[\mathrm{mg} / \mathrm{L}]}\end{array}$ & $\begin{array}{c}\text { Glucose } \\
{[\mathrm{mg} / \mathrm{L}]}\end{array}$ & $\begin{array}{c}\mathrm{nDy} \\
{[\mathrm{mg} / \mathrm{O}}\end{array}$ \\
\hline \multirow{3}{*}{850} & 70 & $0^{*}, 0.02,0.2,2$ \\
\hline & 140 & $0^{*}, 0.02,0.2,2$ \\
\hline \multirow{5}{*}{8500} & $0^{*}$ & $0.02,0.2,2$ \\
\cline { 2 - 3 } & 35 & $0^{*}, 0.02,0.2,2$ \\
\cline { 2 - 3 } & 70 & $0^{*}, 0.02,0.2,2$ \\
\cline { 2 - 3 } & 140 & $0^{*}, 0.02,0.2,2$ \\
\hline & $0^{*}$ & $0.02,0.2,2$ \\
\cline { 2 - 3 } & 35 & $0^{*}, 0.02,0.2,2$ \\
\cline { 2 - 3 } & 70 & $0^{*}, 0.02,0.2,2$ \\
\cline { 2 - 3 } & 140 & $0^{*}, 0.02,0.2,2$ \\
\hline
\end{tabular}

\subsection{Toxicity tests}

2.3.1. Respirometric test. Cell respiration in non-growing conditions was quantified through the reduction of tetrazolium dye ${ }^{\mathbf{2 1 , 2 2}}$. When a carbon source is consumed, metabolic activity transports electrons from the carbon source to the electron transport chain in the cell membrane where the tetrazolium dye is reduced, which in turn produces a purple colour ${ }^{23,24}$. The purple colour can be quantified in terms of absorbance using a microplate reader at a wavelength of $590 \mathrm{~nm}^{25}$. The plate was prepared first by adding $\mathrm{NaCl}$, then glucose, $\mathrm{nDy}_{2} \mathrm{O}_{3}$, tetrazolium dye, and finally a bacteria solution were directly inoculated into a Blank 96 half-area well microplate to achieve the required concentrations. The final volume within each well was $100 \mu \mathrm{L}$, mixed thoroughly by pipetting at least 10 times. Glucose, $\mathrm{nDy}_{2} \mathrm{O}_{3}$, and cell solutions were all prepared in the respective saline solution. Experiments were run for $2.5 \mathrm{hrs}$ and readings were recorded every $0.25 \mathrm{hrs}$ after every horizontal shaking (medium setting) performed by the microplate reader. Data was analyzed at 0.25 and $2 \mathrm{hrs}$. The two-hour interval was selected in order to distinguish the effect between nanoparticles before and after aggregation. Aggregation increased drastically after $2 \mathrm{hrs}$, particularly for those conditions with high concentrations of $\mathrm{NaCl}$. Higher exposure time could increase toxicity effect; however, for time periods longer than $2 \mathrm{~h}$, the toxicity results will not be because of the dysprosium nanoparticles but because of the dysprosium microparticules. The microplates were incubated at $25^{\circ} \mathrm{C}$. A detailed description of the microplate set-up is presented in the Supplemental Information section.

The microplate included $\mathrm{nDy}_{2} \mathrm{O}_{3}$ blank, and background correction sections to evaluate the interaction between nanoparticles and tetrazolium dye. Lack of coloration in the $\mathrm{nDy}_{2} \mathrm{O}_{3}$ blank section indicated that no interaction was observed between $\mathrm{nDy}_{2} \mathrm{O}_{3}$ and the tetrazolium dye. For the background (absorbance of $\mathrm{nDy}_{2} \mathrm{O}_{3}$ ) correction, the value obtained in the respective well, was subtracted from the experiment values and also served as a secondary control to confirm that experimental conditions had no reducing effect on the tetrazolium dye without the presence of bacteria.
Each plate has been set up in quadruplicate wells for each condition, and the plates were run in duplicate to quantify the percent of remaining respiration (PRR). The PRR (Eq. 1) is the ratio of slopes between bacteria exposed to $\mathrm{nDy}_{2} \mathrm{O}_{3}$ and the blank bacteria (samples containing bacteria that were not exposed to $\mathrm{nDy}_{2} \mathrm{O}_{3}$ ) at a specific $\mathrm{nDy}_{2} \mathrm{O}_{3}$ concentration from the absorbance-time graph.

$\mathrm{PRR}=\frac{P_{t}}{P_{c}} \cdot \mathbf{1 0 0} \%$

Where,

$\mathrm{P}_{\mathrm{t}}=$ slope from absorbance-time graph for bacteria exposed to $\mathrm{nDy}_{2} \mathrm{O}_{3}$

$\mathrm{P}_{\mathrm{c}}=$ slope from absorbance-time graph for bacteria control without $\mathrm{nDy}_{2} \mathrm{O}_{3}$

2.3.2. Live/dead test. The cell membrane permeation of $E$. coli was determined using the Backlight kit (propidium iodide and SYTO 9) with the microplate reader. Propidium iodide becomes intercalated to the DNA within cells, and indicates bacteria that have a damaged membrane. SYTO 9, on the other hand, indicates intact cell membranes ${ }^{14}$. A stain solution composed of SYTO 9 and propidium iodide fluorescent nucleic acid stains was mixed at a 1:1 $(\mathrm{v} / \mathrm{v})$ ratio with a subsequent dilution in DI water $(12 \mu \mathrm{L}$ of stain mixed solution in $2 \mathrm{~mL}$ of DI water). Suspension mixtures of $\mathrm{NaCl}$, glucose, $\mathrm{nDy}_{2} \mathrm{O}_{3}$, and bacteria were added into separate wells of a 96 well flatbottom black microplate to achieve the required concentrations. The plate was incubated at $25^{\circ} \mathrm{C}$ for $2.0 \mathrm{hrs}$, during which horizontal shaking (medium setting) was performed by the microplate every $0.25 \mathrm{hrs}$. After incubation, $100 \mu \mathrm{l}$ of mixed stain solution was added and mixed thoroughly by pipetting at least 10 times for each well. Before reading with the microplate, $0.25 \mathrm{hrs}$ of additional incubation was required in the dark at room temperature. A detailed description of the microplate setup is presented in the Supplemental Information section. Each plate contained quadriplicate wells for each condition, and each plate was run in duplicate to quantify the undisturbed cell membrane (UCM). The UCM (Eq. 2) is the green/red fluorescence ratio between bacteria exposed to $\mathrm{nDy}_{2} \mathrm{O}_{3}$ and the blank bacteria (bacteria not exposed to $\mathrm{nDy}_{2} \mathrm{O}_{3}$ ) at given $\mathrm{nDy}_{2} \mathrm{O}_{3}$ concentration. Data was analyzed at 0.25 and $2 \mathrm{hrs}$ to differentiate the effect of aggregation of nanoparticles.

$\mathrm{UCM}=\frac{P_{t}}{P_{c}} .100$. Eq. 2

Where,

$P_{t}=$ Green/red fluorescence ratio for bacteria exposed to $\mathrm{nDy}_{2} \mathrm{O}_{3}$

$\mathrm{P}_{\mathrm{c}}=$ Green/red fluorescence ratio for bacteria control without $\mathrm{nDy}_{2} \mathrm{O}_{3}$

2.3.3. Toxicity tests for $\mathrm{nDy}_{2} \mathrm{O}_{3}$ ion release. Additional experiments using the respective ions concentration, released at the highest concentration of $\mathrm{nDy}_{2} \mathrm{O}_{3}$, were performed. These experiments allow us to determine the contribution of Dy ions to the overall toxicity 
on E. coli. Similar method was used to prepare the plate, but dysprosium ions were used instead of $\mathrm{nDy}_{2} \mathrm{O}_{3}$.

\subsection{Statistical analysis}

The results from each data set were analyzed with SAS statistical software, version 9.1.2. A generalized linear mixer model (GLIMMIX) was used to identify statistical differences among glucose, $\mathrm{NaCl}$, and $\mathrm{nDy}_{2} \mathrm{O}_{3}$ concentrations because the response was not necessarily normally distributed. A $p$ value of less than 0.05 was considered to indicate significant difference.

\section{Results and Discussion}

\subsection{Physiochemical characterization of $\mathrm{nDy}_{2} \mathrm{O}_{3}$}

3.1.1. Size and zeta potential without bacteria. Uncoated $\mathrm{nDy}_{2} \mathrm{O}_{3}$ characterization consisted of size and zeta potential measurements in two of the three water chemistry conditions. Tests with 8500 $\mathrm{mg} / \mathrm{L} \mathrm{NaCl}$ were discontinued due to interference between tetrazolium dye and $\mathrm{NaCl}$. Details will be explained in Section 3.2. Figure 1 shows size (a) and zeta potential (b) measurement at 0 , 0.25 and $2.0 \mathrm{hrs}$ for the highest concentration of $2.0 \mathrm{mg} / \mathrm{L}$ of $\mathrm{nDy}_{2} \mathrm{O}_{3} . \mathrm{nDy}_{2} \mathrm{O}_{3}$ sizes from 0 to 0.25 hrs at all water chemistry conditions were in the range of 75 to $150 \mathrm{~nm}$; however, size measurements at $2 \mathrm{hrs}$ showed an increase in $\mathrm{nDy}_{2} \mathrm{O}_{3}$ particle size, indicating aggregation. It was observed that aggregation increased when the ionic strength was higher $(850 \mathrm{mg} / \mathrm{L} \mathrm{NaCl})$, and also at all glucose concentrations. This may be attributed to the absence of a coating agent on the nanoparticles surface and lower repelling forces as a result of high ionic strength in the solution. Zeta potential measurements (Figure $1 \mathrm{~b}$ ) showed the instability of $\mathrm{nDy}_{2} \mathrm{O}_{3}$ with surface charge measurements ranging between 6 and $23 \mathrm{mV}$ in 85 and $850 \mathrm{mg} / \mathrm{L}$ of $\mathrm{NaCl}$ during 2 hrs of contact time.

3.1.2. Shape and $\mathrm{pH}$. TEM imaging confirmed the shape of the $\mathrm{nDy}_{2} \mathrm{O}_{3}$ to be spherical (Figure 2). Nanoparticles were found to have an average size of $74.8 \pm 5 \mathrm{~nm}$. Changes in $\mathrm{H}^{+}$ions before and after nanoparticle exposure were recorded periodically with a $\mathrm{pH}$ meter. The $\mathrm{pH}$ measurements at $\mathrm{t}=0 \mathrm{hrs}$ and $\mathrm{t}=2 \mathrm{hrs}$ ranged from 5.5 to 6.2 , indicating that $\mathrm{pH}$ did not function as an additional stress on bacteria performance. Moreover, there was no statistically significant change.

3.1.3. Ion release. Ion release experiments were conducted for the highest concentration of $\mathrm{nDy}_{2} \mathrm{O}_{3},(2.0 \mathrm{mg} / \mathrm{L})$, which was the most toxic condition for E. coli. Dy ions were measured in all water chemistry and glucose conditions to determine the amount of dissolution over time. Table 3-1 shows a sudden increase in Dy ions measured at $0 \mathrm{hrs}$ and $0.25 \mathrm{hrs}$, with a plateau occurring at $2.0 \mathrm{hrs}$.

4 | J. Name., 2012, 00, 1-3
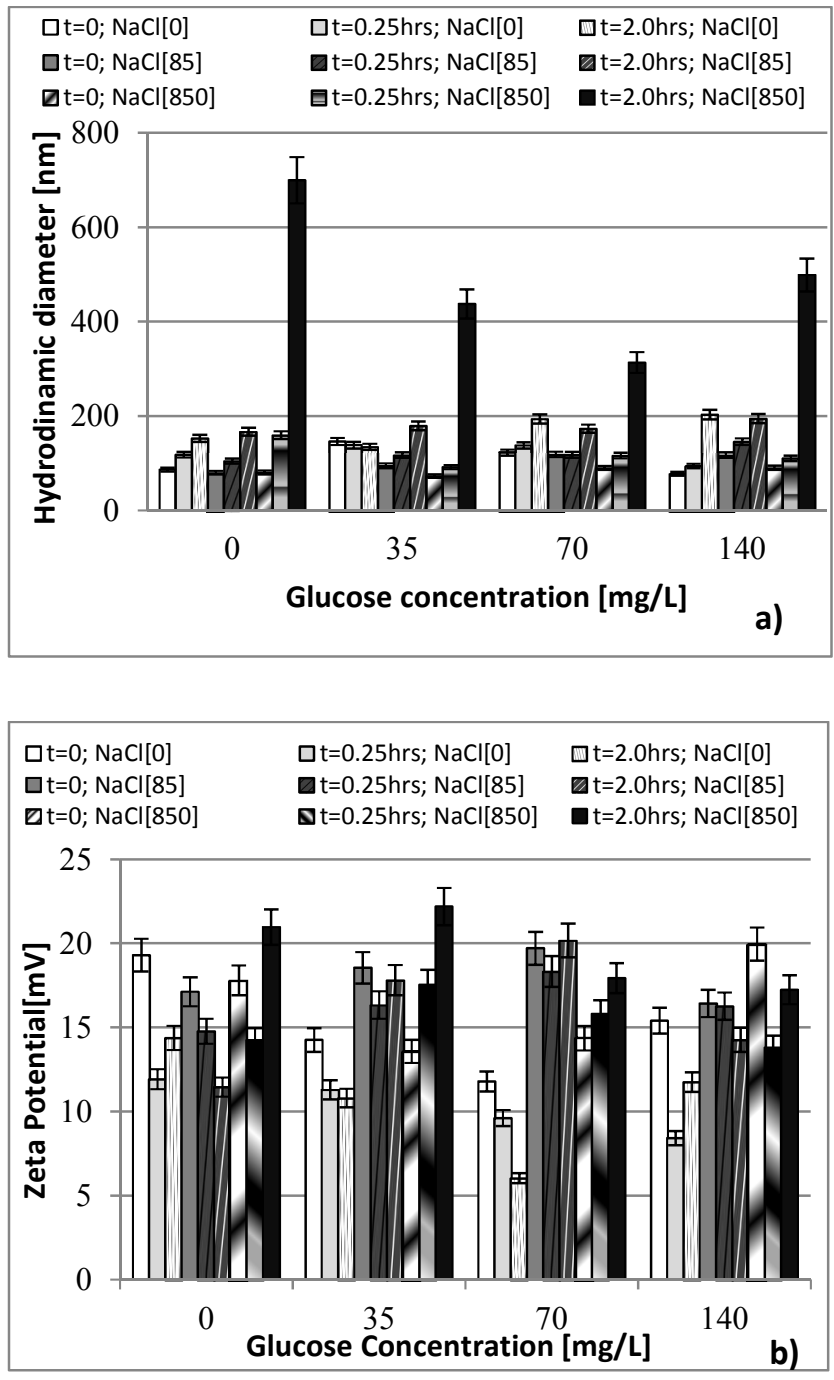

Figure 1 Size (a) and zeta potential (b) measurements in samples containing $35 \mathrm{mg} / \mathrm{L}, 70 \mathrm{mg} / \mathrm{L}$, and $140 \mathrm{mg} / \mathrm{L}$ glucose, and $2.0 \mathrm{mg} / \mathrm{L} \mathrm{nDy}{ }_{2} \mathrm{O}_{3}$. Measurements were taken at $0 \mathrm{hrs}, 0.25 \mathrm{hrs}$ and $2 \mathrm{hrs}$.

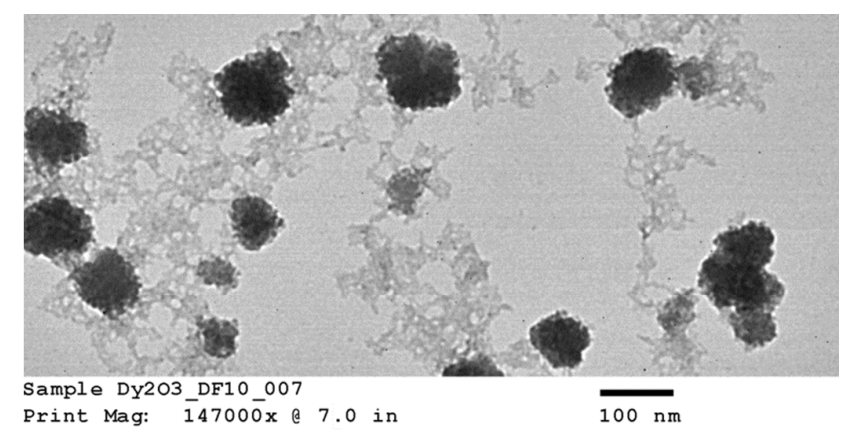

Figure $2 \mathrm{nDy}_{2} \mathrm{O}_{3}$ TEM image shows the spherical nanoparticles with average diameter of $74.8 \mathrm{~nm}$. 
Table 2 lon release concentration for $2.0 \mathrm{mg} / \mathrm{LnDy}_{2} \mathrm{O}_{3}$ in samples containing $85 \mathrm{mg} / \mathrm{L}$ and $850 \mathrm{mg} / \mathrm{L} \mathrm{NaCl}$, and $35 \mathrm{mg} / \mathrm{L}, 70 \mathrm{mg} / \mathrm{L}$ and $140 \mathrm{mg} / \mathrm{L}$ glucose. Measurements were taken at $0 \mathrm{hrs}, 0.25 \mathrm{hrs}$ and $2.0 \mathrm{hrs}$.

\begin{tabular}{|c|c|c|c|c|}
\hline \multirow{2}{*}{$\begin{array}{c}\mathrm{NaCl} \\
{[\mathrm{mg} / \mathrm{L}]}\end{array}$} & \multirow{2}{*}{$\begin{array}{c}\text { Glucose } \\
{[\mathrm{mg} / \mathrm{L}]}\end{array}$} & \multicolumn{3}{|c|}{ Dy ions $[\mathrm{mg} / \mathbf{L}]$} \\
\cline { 3 - 5 } & 35 & $\mathbf{t}=\mathbf{0 h r s}$ & $\mathbf{t}=\mathbf{0 . 2 5} \mathbf{~ h r s}$ & $\mathbf{t}=\mathbf{2} \mathbf{~ h r s}$ \\
\cline { 2 - 5 } & 35 & 0.40 & 0.65 & 0.70 \\
\cline { 2 - 5 } & 70 & 0.42 & 0.68 & 0.72 \\
\hline \multirow{3}{*}{850} & 140 & 0.43 & 0.69 & 0.75 \\
\cline { 2 - 5 } & 35 & 0.47 & 0.64 & 0.73 \\
\cline { 2 - 5 } & 70 & 0.48 & 0.68 & 0.75 \\
\cline { 2 - 5 } & 140 & 0.49 & 0.68 & 0.79 \\
\hline
\end{tabular}

\subsection{Toxicity tests}

Respirometric tests at $8,500 \mathrm{mg} / \mathrm{L}$ of $\mathrm{NaCl}$ detected interference between tetrazolium dye and $\mathrm{NaCl}$. Bacteria at 85 and $850 \mathrm{mg} / \mathrm{L}$ of $\mathrm{NaCl}$ without stress conditions maintained an absorbance value after the dye was reduced. On the other hand, bacteria at $8,500 \mathrm{mg} / \mathrm{L}$ showed the opposite behaviour (see $\mathrm{SI}$ ). Interference with glucose was discarded because Live/Dead tests showed no problems under similar condition. Although, absorbance measurements could not be obtained at high $\mathrm{NaCl}$ concentration, it is known that $E$. coli may survive under high ionic strength conditions similar to those presented in this study ${ }^{26-28}$.

3.2.1. Respirometric test. The PRR compares the slope values representing respiration of the remaining bacteria after $\mathrm{nDy}_{2} \mathrm{O}_{3}$ exposure with the slope values of the control wells. In the control wells, bacteria were not exposed to $\mathrm{nDy}_{2} \mathrm{O}_{3}$. Figure 3 shows the PRR for all water chemistry conditions tested at 0.25 and 2 hrs. For 0.25 hrs, no toxicity effect was observed for most glucose concentrations of 35 and $70 \mathrm{mg} / \mathrm{L}$, except for $35 \mathrm{mg} / \mathrm{L}$ of glucose and $0.02 \mathrm{mg} / \mathrm{L}$ of $\mathrm{nDy}_{2} \mathrm{O}_{3}$. This could be due to the fact that the $\mathrm{nDy}_{2} \mathrm{O}_{3}$ contact time was not enough to produce a significant toxicity effect in the bacteria. After $2.0 \mathrm{hrs}$, there was an increase in toxicity for some water chemistry conditions. For $2.0 \mathrm{mg} / \mathrm{L} \mathrm{nDy}_{2} \mathrm{O}_{3}$, the toxicity effect was more pronounced at all glucose and $\mathrm{NaCl}$ concentrations. The greatest toxicity effect (PRR=43\%) was observed at $85 \mathrm{mg} / \mathrm{L} \mathrm{NaCl}$ and $140 \mathrm{mg} / \mathrm{L}$ glucose. The high PRR values may be associated with the metabolic activity at high carbon concentration levels and more stable nanoparticles at low concentrations of $\mathrm{NaCl}$. E. coli increases the carbon mineralization at glucose concentration of $140 \mathrm{mg} / \mathrm{L}$, where Dy ions can be transported inside the bacteria that are coupled to an essential metal uptake by the cells ${ }^{29}$.

3.2.2. Live/Dead test. The undisturbed cell membrane (UCM) results are shown in Figure 4. Live/Dead experiments detected a very low toxicity effect of $\mathrm{nDy}_{2} \mathrm{O}_{3}$ on $E$. coli under the same conditions used for the respirometric microarray tests. The results showed no significant membrane permeation, which means minimal ( $U C M=94.9)$ to no physical damage to $E$. coli occurred at $\mathrm{nDy}_{2} \mathrm{O}_{3}$ concentrations ranging from 0.02 to $0.2 \mathrm{mg} / \mathrm{L}$. Only at high concentrations of $\mathrm{nDy}_{2} \mathrm{O}_{3}(2 \mathrm{mg} / \mathrm{L})$ and at ionic strength $(850 \mathrm{mg} / \mathrm{L}$
$\mathrm{NaCl})$, a slight toxicity effect $(\mathrm{UCM}=88.5)$ was observed on bacteria. However, it was less pronounced compared to the toxicity effect results obtained for the respirometric test. The increasing concentrations of glucose seem to show no constant trend. Thus, glucose concentration could not have influence the toxicity effect results.

3.2.3.Effect of Dy ions on $E$. coli Toxicity. Additional experiments were performed to determine the contribution of Dy ions to the overall toxicity on E. coli. The tests were performed using the respective ions concentration released at the highest concentration of $\mathrm{nDy}_{2} \mathrm{O}_{3}$ (table 2), as that exhibited the highest toxicity effect on bacteria. The results showed that cell viability was predominantly lost due to interactions of $\mathrm{Dy}^{+3}$ ions with $E$. coli rather than $\mathrm{nDy}_{2} \mathrm{O}_{3}$ (Figure 5). This suggests that $\mathrm{nDy}_{2} \mathrm{O}_{3}$ could have caused damage to the cell membrane, and $\mathrm{Dy}^{+3}$ could have entered into the cell and disturbed intracellular activities, as previously presented.

\subsection{Comparison between toxicology methodologies}

This study performed a comparison between two toxicological tests using $\mathrm{nDy}_{2} \mathrm{O}_{3}$ on E. coli. It was found that for both methodologies, and at the same conditions, $\mathrm{nDy}_{2} \mathrm{O}_{3}$ is most toxic at high concentrations $[2.0 \mathrm{mg} / \mathrm{L}]$. The respirometric test showed a more prominent response ( $\mathrm{PRR}=43 \%)$ compared to Live/Dead $(U C M=88 \%)$ test. This indicates that metabolic responses are more sensitive to toxicity than cell physiology when bacteria are exposed to $\mathrm{nDy}_{2} \mathrm{O}_{3}$.

Statistical analysis (for details, see Supplemental Information section) confirmed a correlation - first with the $\mathrm{nDy}_{2} \mathrm{O}_{3}$ concentrations $(p<0.0001)$, then with $\mathrm{NaCl}$ concentrations $(p=0.0040)$ and finally with glucose concentrations $(p=0.0074)$ on the exposure response to $\mathrm{nDy}_{2} \mathrm{O}_{3}$ for the metabolic activity of the cell. For both methods, $\mathrm{nDy}_{2} \mathrm{O}_{3}$ concentration was the most influential variable and determined the magnitude of the exposure response. In addition, a strong correlation was observed when the combined effect between $\mathrm{NaCl}$ and $\mathrm{nDy}_{2} \mathrm{O}_{3}$ $(p=0.0148)$ was analyzed. This is consistent with the results obtained, which showed higher toxicity effect in conditions with low $\mathrm{NaCl}$ and high $\mathrm{nDy}_{2} \mathrm{O}_{3}$ concentrations. Also, $\mathrm{NaCl}$ and glucose were analysed simultaneously showed a significant correlation with a $\mathrm{p}$ value of 0.0566 . Similar trend was observed in the high toxicity effect of $\mathrm{nDy}_{2} \mathrm{O}_{3}$ on $E$. coli when bacteria were more active at high glucose concentrations and $\mathrm{nDy}_{2} \mathrm{O}_{3}$ more stable at low concentrations of $\mathrm{NaCl}$. 

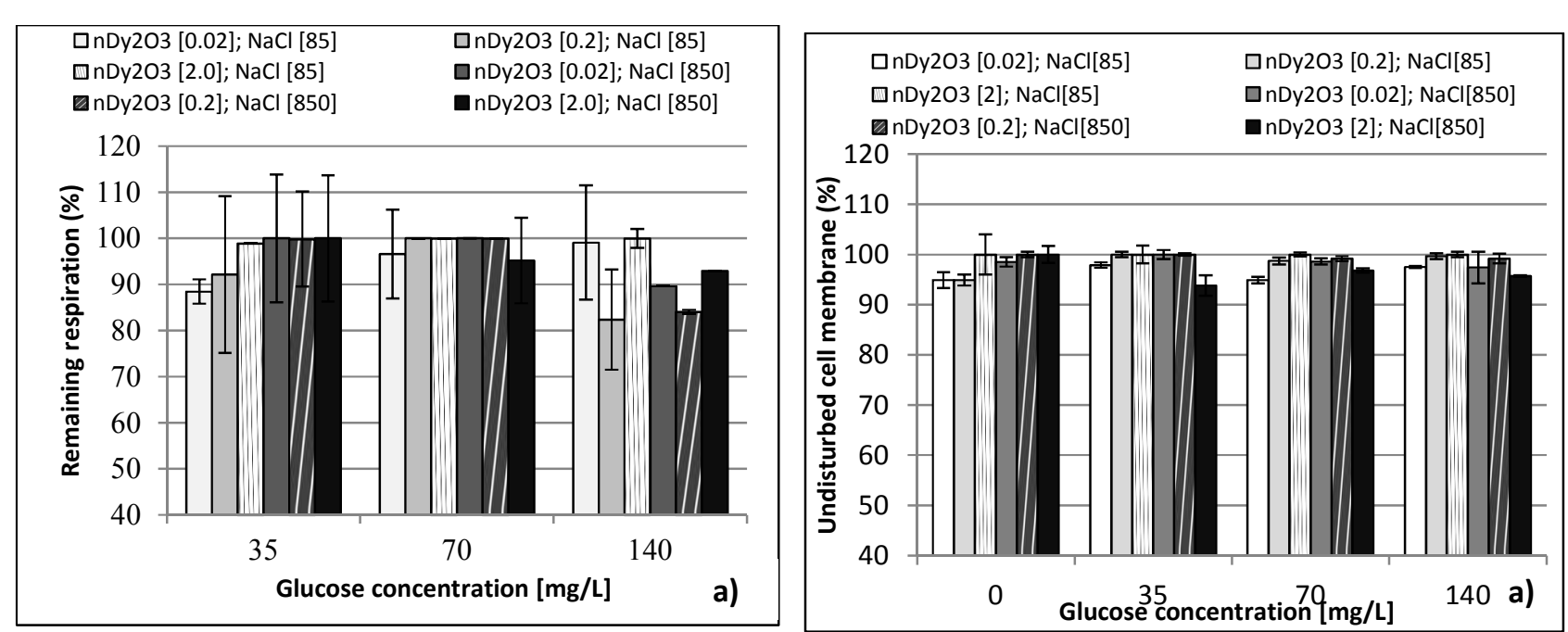

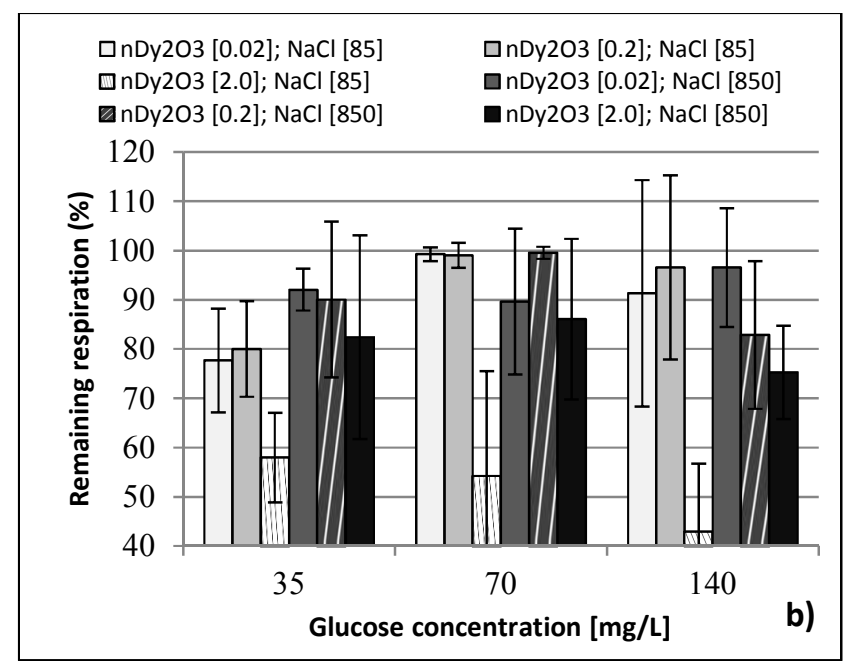

Figure 3 Percent remaining respiration (PPR) of $E$. coli under different water chemistry conditions, $(\mathrm{NaCl} 85 \mathrm{mg} / \mathrm{L}$ and $850 \mathrm{mg} / \mathrm{L})$, and glucose concentration (35 mg/L, $70 \mathrm{mg} / \mathrm{L}$ and $140 \mathrm{mg} / \mathrm{L})$. PPR values were calculated for three concentrations of $\mathrm{nDy}_{2} \mathrm{O}_{3}, 0.02 \mathrm{mg} / \mathrm{L}, 0.2 \mathrm{mg} / \mathrm{L}$ and 2.0 $\mathrm{mg} / \mathrm{L}$ at (a) $0.25 \mathrm{hrs}$ and (b) $2.0 \mathrm{hrs}$. Values are mean from 4 wells and duplicate plates.

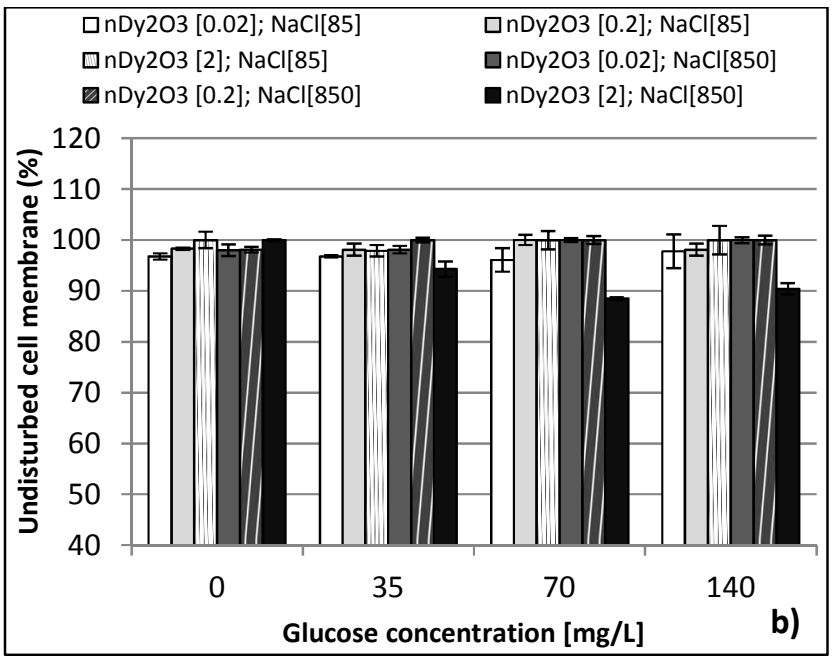

Figure 4 Undisturbed cell membrane (UCM) of E. coli under different water chemistry conditions, $(\mathrm{NaCl} 85 \mathrm{mg} / \mathrm{L}$ and $850 \mathrm{mg} / \mathrm{L})$, and glucose concentration ( $35 \mathrm{mg} / \mathrm{L}, 70 \mathrm{mg} / \mathrm{L}$ and $140 \mathrm{mg} / \mathrm{L}$ ). UCM values were calculated for three concentrations of $\mathrm{nDy}_{2} \mathrm{O}_{3}, 0.02 \mathrm{mg} / \mathrm{L}, 0.2 \mathrm{mg} / \mathrm{L}$ and 2.0 $\mathrm{mg} / \mathrm{L}$ at (a) $0.25 \mathrm{hrs}$ and (b) $2.0 \mathrm{hrs}$. Values are mean from 4 wells and duplicate plates. 

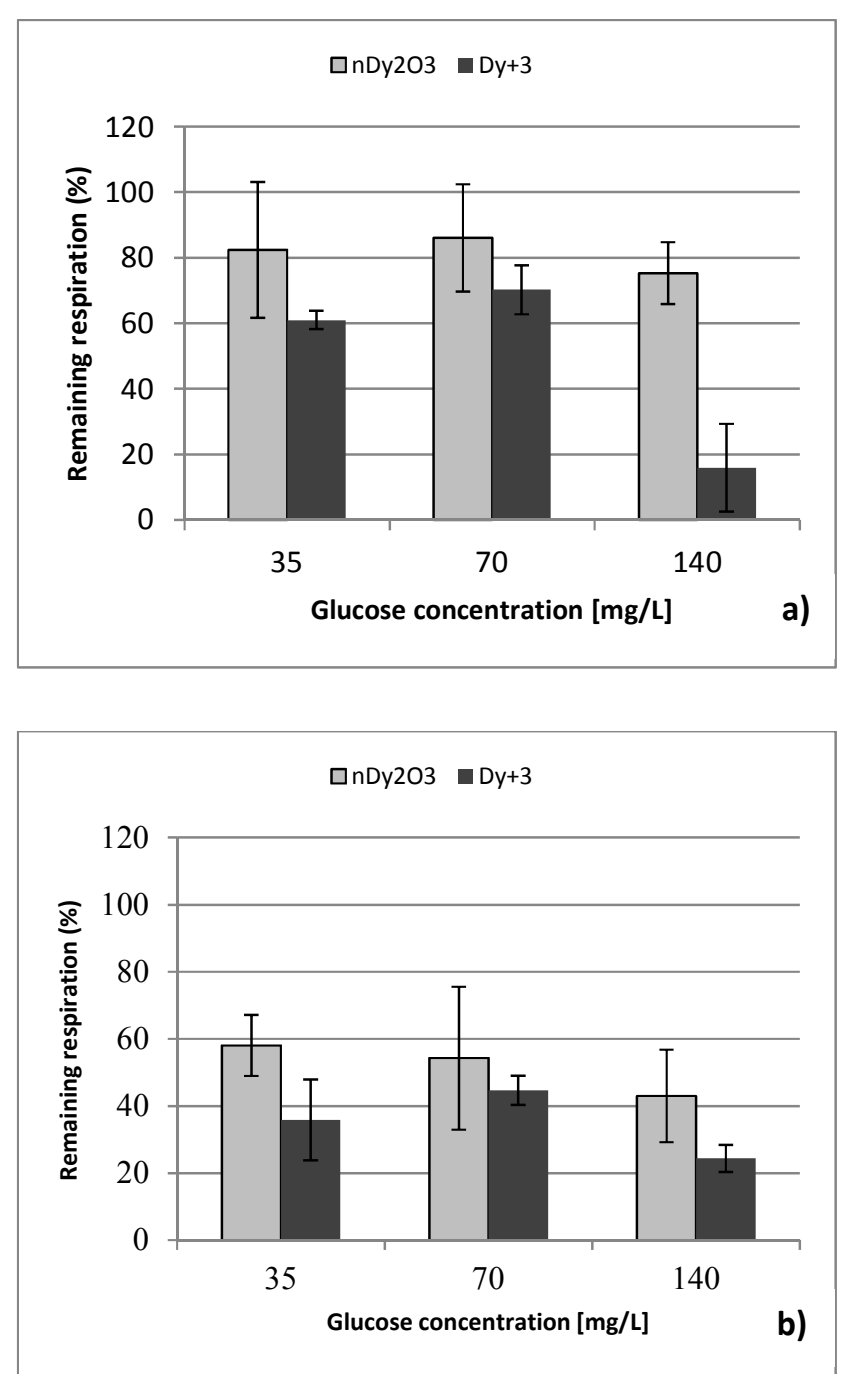

Figure 5 Toxicity effect of dysprosium ions $\left(\mathrm{Dy}^{+3}\right)$ and $\mathrm{nDy}_{2} \mathrm{O}_{3}$ under different water chemistry conditions: (a) $850 \mathrm{mg} / \mathrm{L}$ and b) $85 \mathrm{mg} / \mathrm{L}$ ) and glucose concentration ( $35 \mathrm{mg} / \mathrm{L}, 70 \mathrm{mg} / \mathrm{L}$, and $140 \mathrm{mg} / \mathrm{L}$ ) at the highest concentration of ions released after $2 \mathrm{hrs}$ for $2 \mathrm{mg} / \mathrm{L}$ of $\mathrm{nDy}_{2} \mathrm{O}_{3}$.

\section{Conclusion}

The results showed that respirometric and permeation membrane tests can be used to provide a comprehensive assessment of nanoparticle toxicity on microorganisms. This study evaluated the performance of two toxicity methodologies: the Live/Dead assay to evaluate the membrane permeation, and the respirometric assay to evaluate the metabolic activity of bacteria. The respirometric microarray test proved to be more sensitive than the Live/Dead test in measuring nanoparticle toxicity.

With an understanding of the fate of nanoparticles in aqueous media, a careful selection of appropriate toxicological methodologies can be made to improve the accuracy of future nanotoxicological studies.

\section{Acknowledgements}

Rhode Island Department of Transportation (RIDOT), for partially supporting Nelson M. Anaya, National Aeronautics and Space Administration (NASA) for partially supporting Farrah Solomon and the National Science Funding (NSF), awards 1203555 and 0854113.

\section{References}

1 Y. Zhang, W. Wei, G. K. Das and T. T. Yang Tan, J. Photochem. Photobiol. C Photochem. Rev., 2014, 20, 71-96.

2 W. Xu, K. Kattel, J. Y. Park, Y. Chang, T. J. Kim and G. H. Lee, Phys. Chem. Chem. Phys., 2012, 14, 12687-12700.

3 B. A. Bony, J. S. Baeck, Y. Chang, J. E. Bae, K. S. Chae and G. H. Lee, Biomater. Sci., 2014, 2, 1287-1295.

4 T. Kubik, K. Bogunia-Kubik and M. Sugisaka, Curr. Pharm. Biotechnol., 2005, 6, 17-33.

5 K. Kattel, J. Y. Park, W. Xu, H. G. Kim, E. J. Lee, B. A. Bony, W. C. Heo, S. Jin, J. S. Baeck, Y. Chang, T. J. Kim, J. E. Bae, K. S. Chae and G. H. Lee, Biomaterials, 2012, 33, 3254-3261.

6 G. K. Das, N. J. J. Johnson, J. Cramen, B. Blasiak, P. Latta, B. Tomanek and F. C. J. M. van Veggel, J. Phys. Chem. Lett., 2012, 3, 524-529.

7 T. G. Goonan, Rare earth elements - End use and recyclability: Scientific Investigations, US Geological Survey, 2011.

8 M. Hofmann-Amtenbrink, H. Hofmann and X. Montet, Swiss Med. Wkly., 2010.

9 A. Valavanidis and T. Vlachogianni, Sci Adv Env. Toxicol Ecotoxicol Issues Httpwww Chem-Tox-Ecotox Org, 2010.

10 S. K. Brar, M. Verma, R. D. Tyagi and R. Y. Surampalli, Waste Manag., 2010, 30, 504-520.

11 G. E. Batley, J. K. Kirby and M. J. McLaughlin, Acc. Chem. Res., 2013, 46, 854-862.

12 K. Kattel, J. Y. Park, W. Xu, H. G. Kim, E. J. Lee, B. A. Bony, W. C. Heo, J. J. Lee, S. Jin, J. S. Baeck, Y. Chang, T. J. Kim, J. E. Bae, K. S. Chae and G. H. Lee, ACS Appl. Mater. Interfaces, 2011, 3, 3325-3334.

13 C. U. S. Harper, J. Exp. Nanosci., 2008, 3, $195-206$.

14 L. Boulos, M. Prévost, B. Barbeau, J. Coallier and R. Desjardins, J. Microbiol. Methods, 1999, 37, 77-86.

15 H. Zhang and V. Oyanedel-Craver, J. Environ. Eng., 2012, 138, 58-66.

16 M. Doudoroff, J. Gen. Physiol., 1940, 23, 585-611.

17 H. Zhang and V. Oyanedel-Craver, J. Hazard. Mater., 2013, 260, 272277.

18 L. A. S. Varun K. Kasaraneni, Acs Sustain. Chem. Amp Eng., 2014.

19 J. Liu and R. H. Hurt, Environ. Sci. Technol., 2010, 44, 2169-2175.

20 K. Van Hoecke, K. A. C. De Schamphelaere, P. Van der Meeren, G. Smagghe and C. R. Janssen, Environ. Pollut., 2011, 159, 970-976.

21 A. Omsland and R. A. Heinzen, Annu. Rev. Microbiol., 2011, 65, 111-128.

22 S. Borglin, D. Joyner, K. M. DeAngelis, J. Khudyakov, P. D'haeseleer, M. P. Joachimiak and T. Hazen, Curr. Opin. Biotechnol., 2012, 23, 41-48.

23 B. R. Bochner, P. Gadzinski and E. Panomitros, Genome Res., 2001, 11, 1246-1255.

24 V. Tremaroli, M. L. Workentine, A. M. Weljie, H. J. Vogel, H. Ceri, C. Viti, E. Tatti, P. Zhang, A. P. Hynes, R. J. Turner and D. Zannoni, Appl. Environ. Microbiol., 2009, 75, 719-728.

25 B. Klimek and M. Niklińska, Bull. Environ. Contam. Toxicol., 2007, 78, 112-117. 
26 R. F. Vaccaro, M. P. Briggs, C. L. Carey and B. H. Ketchum, Am. J. Public Health Nations Health, 1950, 40, 1257-1266.

27 Y. Rozen and S. Belkin, FEMS Microbiol. Rev., 2001, 25, 513-529.

28 P. Arense, V. Bernal, J. L. Iborra and M. Cánovas, Process Biochem., 2010, 45, 1459-1467.

29 L. Brynhildsen, B. V. Lundgren, B. Allard and T. Rosswall, Appl. Environ. Microbiol., 1988, 54, 1689-1693. 